\title{
Expenditure Rules: Effective Tools for Sound Fiscal Policy?
}




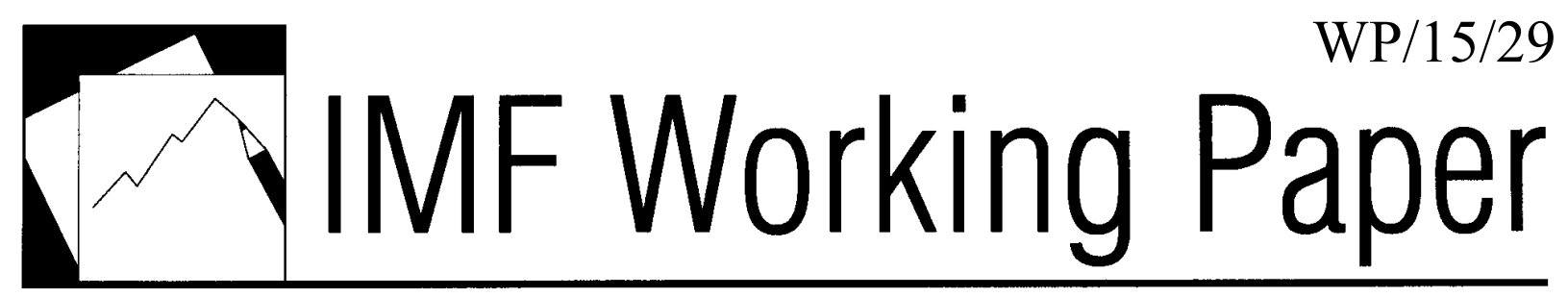

Expenditure Rules: Effective Tools for Sound Fiscal Policy?

Till Cordes, Tidiane Kinda, Priscilla Muthoora, and Anke Weber 


\title{
IMF Working Paper
}

Fiscal Affairs Department

\section{Expenditure Rules: Effective Tools for Sound Fiscal Policy?*}

\section{Prepared by Till Cordes, Tidiane Kinda, Priscilla Muthoora, and Anke Weber}

Authorized for distribution by Julio Escolano

February 2015

\section{This Working Paper should not be reported as representing the views of the IMF.} The views expressed in this Working Paper are those of the author(s) and do not necessarily represent those of the IMF or IMF policy. Working Papers describe research in progress by the author(s) and are published to elicit comments and to further debate.

\begin{abstract}
This paper provides new evidence on the effectiveness of expenditure rules. The analysis is based on a unique dataset covering all countries with national and supranational fiscal rules, including 33 expenditure rules, between 1985 and 2013. It contributes to the existing literature on fiscal rules in two main ways. First, it is the most comprehensive assessment of compliance with rules and of the potential role of expenditure rules, in particular regarding long-term sustainability. Second, it analyzes whether expenditure rules are associated with changes in public investment and its efficiency.
\end{abstract}

JEL Classification Numbers: E62, H5

Keywords: Expenditure rules, Fiscal governance, Fiscal policy, Rules versus discretion, Stabilization

Authors’ E-Mail Addresses: mail@till-cordes.de; tkinda@imf.org; pmuthoora@imf.org; aweber@imf.org

\footnotetext{
* We would like to thank Nate Arnold, Nina Budina, Xavier Debrun, Julio Escolano, Johannes Eugster, Nan Geng, Michael Gorbanyov, Martine Guerguil, Joana Pereira, Marta Ruiz-Arranz, Svetlana Vtyurina, and participants at the FAD seminar series for helpful comments and discussions. We are also grateful to Andrea Schaechter for her encouragements and initial guidance. The main results of this paper were published in the IMF's April 2014 Fiscal Monitor. Ethan Alt and Nathalie Carcenac provided excellent research assistance. All remaining errors are our own.
} 


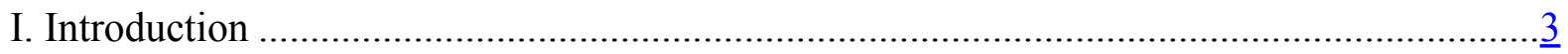

II. What Type of Expenditure Rules Are in Place and What are Their Design Features?......... $\underline{4}$

III. Why Do Countries Adopt and Abandon Expenditure Rules? ....................................... $\underline{8}$

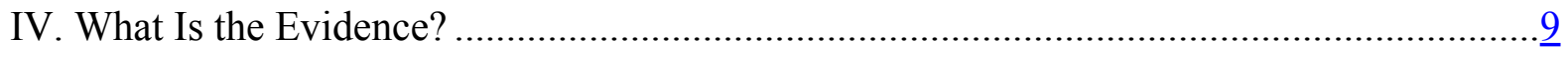

A. Compliance …....................................................................................

B. Expenditure Rules and Long-term Sustainability …................................... $\frac{13}{15}$

C. Other Implications of Expenditure Rules.................................................... 15

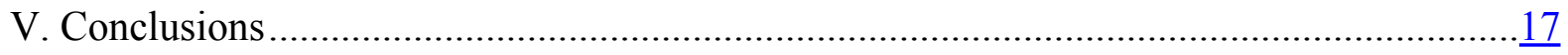

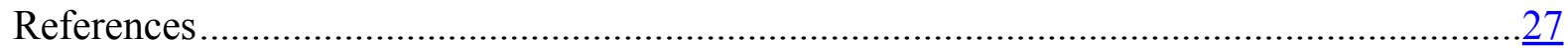

Tables

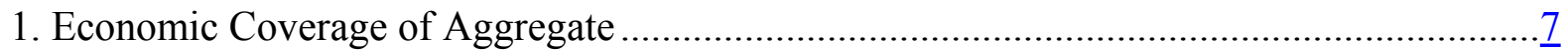

2. Expenditure Rules and Fiscal Performance ..............................................................

3. Unbalanced Fixed Effects Panel Regressions 1980-2010, with Stock-Flow Adjustments as the Dependent Variable ..........................................................................................

Figures

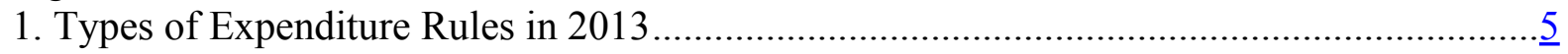

2. Combination of Expenditure Rules with Other National Rules in 2013 ........................... $\frac{5}{6}$

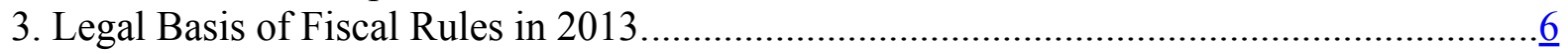

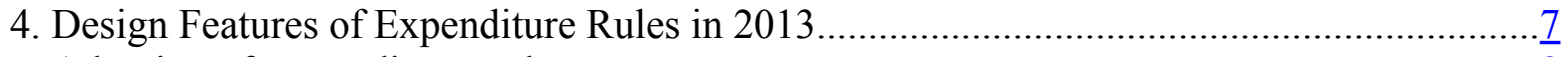

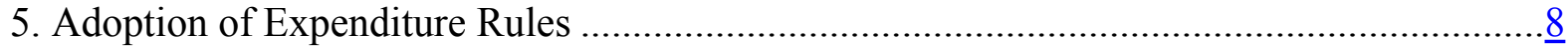

6. Compliance with Fiscal Rules, 1985-2012 ….........................................................

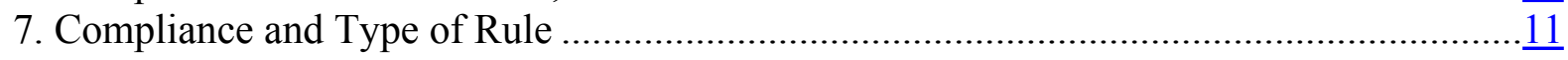

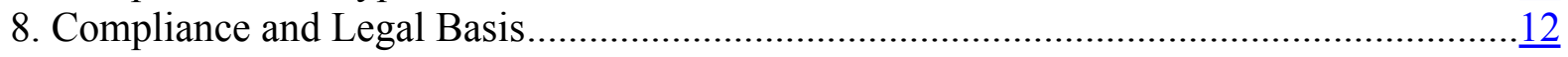

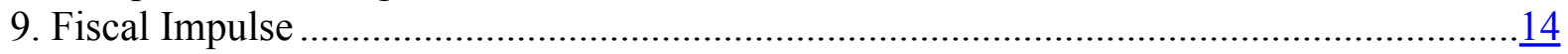

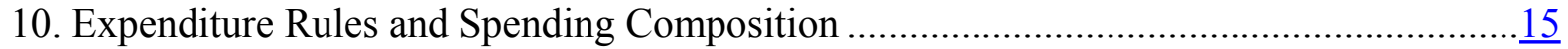

11. Expenditure Rules, Efficiency, and Government Size........................................... $\frac{15}{16}$

12. Expenditure Rules and Medium-Term Frameworks.............................................

Appendices

1. Country List for Regressions on Expenditure Rules and Fiscal Performance ....................18

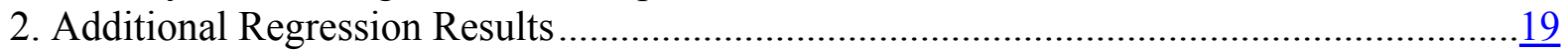

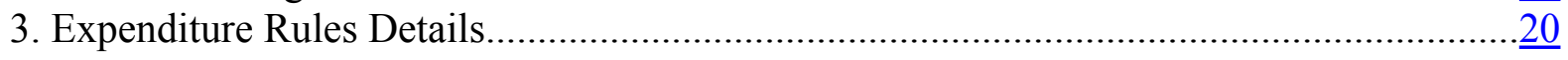

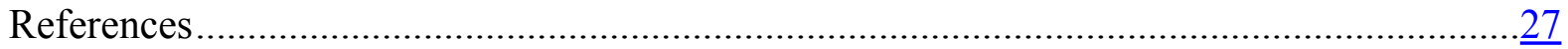




\section{INTRODUCTION}

The role of fiscal institutions in promoting sound fiscal policies has come to the fore of the policy debate in the aftermath of the global financial crisis. The focus on fiscal institutions comes against the backdrop of a marked deterioration in public finances, the sharpest since the end of World War II and the need to regain or strengthen the credibility of fiscal policy in many economies.

Expenditure rules, in particular, have received increasing attention as they exhibit a number of features. ${ }^{1}$ In particular, they are directly aimed at addressing the expenditure pressures often at the origin of excessive deficits, they are transparent and generally easy to monitor, they fully accommodate revenue shortfalls resulting from adverse economic shocks (allowing for a stabilizing role of fiscal policy), and they are most directly related to the formulation of the annual budget, which sets legally binding appropriations, thus contributing to the rules' enforceability. Importantly, and unlike deficit caps, expenditure rules also help creating buffers in good times, when revenue windfalls can make spending pressures difficult to resist (Ayuso-i-Casals, 2012). These countercyclical properties also make expenditure rules particularly attractive for countries where estimates of the structural budget balance are challenging to obtain because the economic cycle is not well-defined (e.g., developing or transition economies and developed small open economies).

A lingering concern however remains about the effect of expenditure rules on the composition of spending. By reducing incentives for spending overruns, expenditure rules can lead to stricter prioritization and greater efficiency in spending. But the interaction of political economy considerations with a binding constraint on total spending may result in the crowding out of productive but electorally unappealing projects (Debrun, 2014).

In this paper, we draw on the fiscal rules database developed by Schaechter and others (2012) to provide the most comprehensive assessment of compliance with fiscal rules. The paper also investigates the effect of expenditure rules on the level and composition of public spending using a sample of 29 countries with expenditure rules between 1985 and 2013.

Our findings suggest that expenditure rules are associated with spending control, counter-cyclical fiscal policy, and improved fiscal discipline. We find that fiscal performance is better in countries where an expenditure rule exists. This appears to be related to the properties of expenditure rules as compliance rates are generally higher than with other types of rules (on the budget balance or debt, for example). In particular, we find that compliance with expenditure

\footnotetext{
${ }^{1}$ In the European Union, for example, national expenditure rules have been reinforced through the inclusion in the "Six-Pack" of an expenditure benchmark to reinforce the preventive arm of the Stability and Growth Pact. Under the expenditure benchmark rule, public spending is not allowed to increase faster than medium-term potential GDP growth, unless it is matched by adequate revenues.
} 
rules is higher if the expenditure target is directly under the control of the government and if the rule is not a mere political commitment, but enshrined in law or in a coalition agreement.

Evidence of adverse side effects is mixed. The introduction of expenditure rules is associated with a decrease in public investment only in emerging economies. A possible explanation is that any adverse effects on public investment could be mitigated in advanced economies by welldesigned budgetary frameworks and procedures.

Instead, the empirical analysis points to two positive side effects. First, expenditure rules reduce the volatility of expenditure, thus imparting a degree of predictability to fiscal policy and making it less destabilizing. Second, expenditure rules are associated with higher public investment efficiency. These results however need to be interpreted with care given the relatively small sample size.

The rest of the paper is structured as follows. Section II provides stylized facts on expenditure rules. In particular, it analyzes who uses expenditure rules and what are the key characteristics of expenditure rules that are (or were) in place. Section III discusses why countries adopt and abandon expenditure rules. Section IV analyzes whether expenditure rules have been effective in practice; section IV.A sheds light on who complied with expenditure rules and when; section IV.B investigates the behavior of primary balances around the introduction of the rules; and section IV.C looks at the response of public investment spending and efficiency following the introduction of expenditure rules. Section V concludes.

\section{What Type of Expenditure Rules Are in Place and What are Their DESIGN Features?}

In this paper, expenditure rules are defined to include both specific numerical targets fixed in legislation and expenditure ceilings for which the targets can be revised, but only on a lowfrequency basis (e.g., as part of the electoral cycle), as long as they are binding for a minimum of three years.

In practice, expenditure rules typically take the form of a cap on nominal or real spending growth over the medium term (Figure 1). Expenditure rules are currently in place in 23 countries (11 in advanced and 12 in emerging economies). Ceilings on real spending growth are relatively more frequent in advanced economies, presumably reflecting better capacity to estimate outlays in real terms. 
Figure 1. Types of Expenditure Rules in 2013

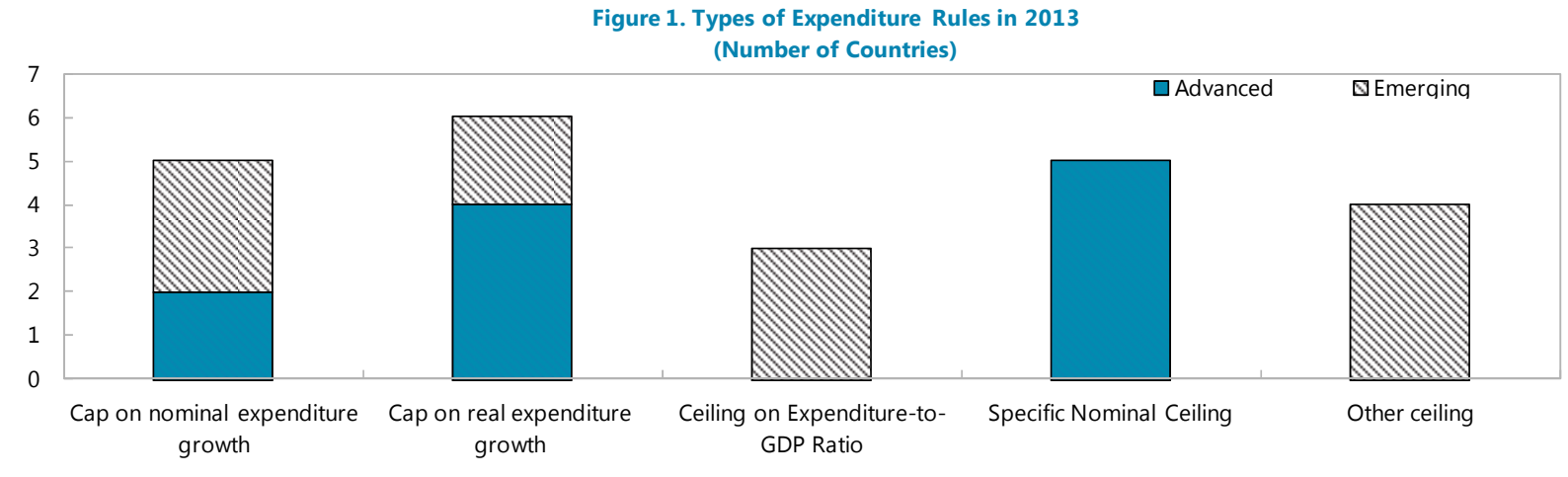

Source: FAD Fiscal Rules Database.

Often, expenditure rules are used in connection with other national rules. The combination of expenditure rules and budget balance rules is particularly common in advanced countries, whereas in emerging countries, they are often used in connection with debt rules (Figure 2). ${ }^{2} \mathrm{~A}$ possible explanation is that not all types of fiscal rules are equally apt to support the sustainability, economic stabilization, and possibly the size of government objectives, even when their design features are fine-tuned. Using a combination of fiscal rules can help address the gaps. For example, an expenditure rule combined with a debt rule would assist policymakers with short to medium-term operational decisions, while allowing for some counter-cyclicality and provide a link to debt sustainability.

Figure 2. Combination of Expenditure Rules with Other National Rules in 2013

(Number of Countries)

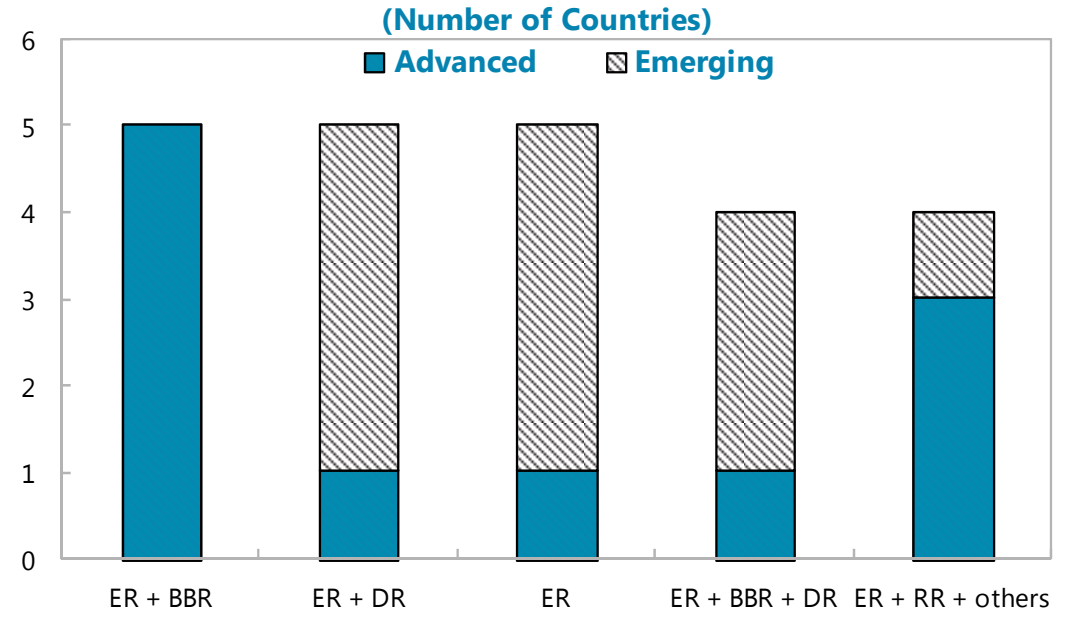

Source: FAD Fiscal Rules Database; and Authors' calculations. Notes: $E R=E x p e n d i t u r e ~ R u l e s ; B B R=$ budget balance rule; $D R=d e b t$ rule, $\mathrm{RR}=$ revenue rule.

\footnotetext{
${ }^{2}$ In the EU-27 countries, there are also the supranational Maastricht budget balance and debt rules.
} 
Expenditure rules are more commonly established through statutory norms in emerging economies than in advanced economies. In advanced economies, expenditure rules tend to be more closely integrated into the Medium-Term Expenditure Frameworks, which are sometimes part of coalition agreements (Figure 3).

Figure 3. Legal Basis of Fiscal Rules in 2013

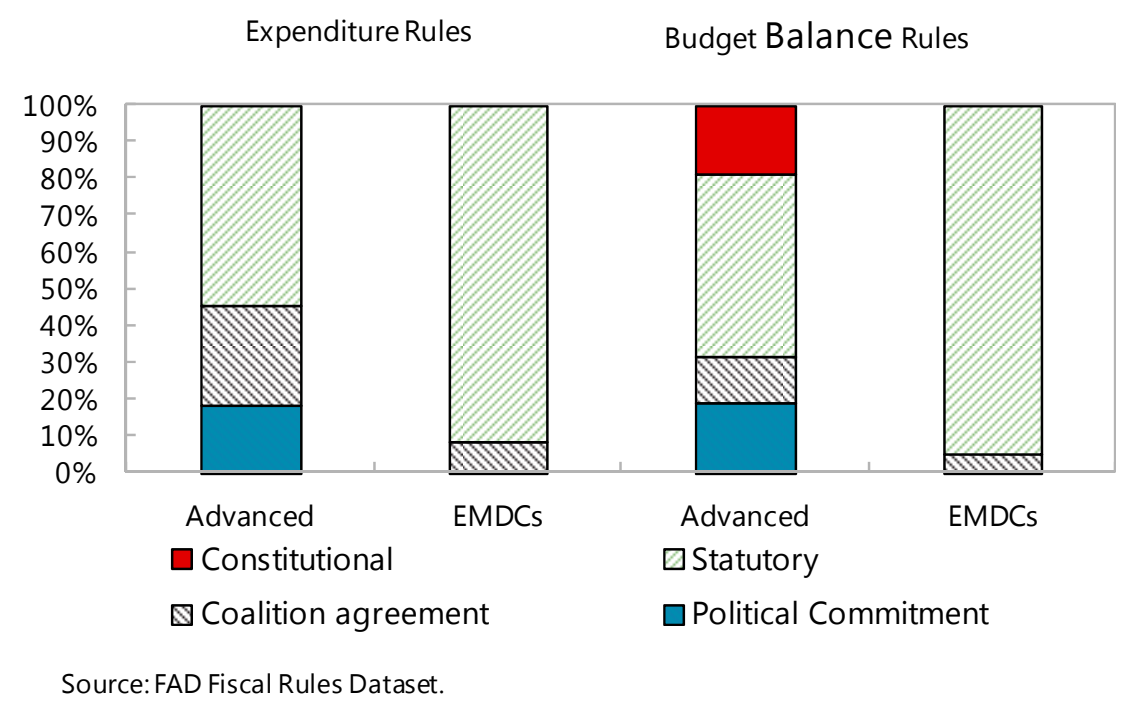

The majority of expenditure rules cover the central government. Of the 23 countries that had an expenditure rule in place in 2013, 15 had one at the central government level and eight at the general government level. ${ }^{3}$ The greater prevalence of rules at the central government level may reflect autonomy and coordination issues with subnational governments.

In terms of economic coverage, a number of items are frequently excluded (Table 1). Fiscal sustainability considerations argue for a more comprehensive coverage but other competing objectives (such as improving the composition of spending) and controllability arguments are put forward to exclude certain items. A broad coverage aims at managing total revenue and expenditure, and makes the target more transparent and easier to monitor. Nevertheless, it is sometimes seen as desirable to exclude, for example, capital expenditure since it is generally expected to positively contribute to long-term growth. However, this can be problematic as it weakens the link with gross debt. Moreover, not all capital expenditure is necessarily productive and, depending on country circumstances, there may be other items such as health care and education expenditure that may raise potential growth even more. Excluding interest payments and cyclically-sensitive expenditure from target variables is also often discussed since they are not under the control of governments in the short run and require short-term adjustments in other

\footnotetext{
${ }^{3}$ The expenditure rule in Sweden covers the central government and the pension system.
} 
expenditure categories, with capital spending often the easiest to cut. An argument for including cyclically-sensitive expenditure is that most cyclical sensitivity is on the revenue side.

Table 1. Economic Coverage of Aggregate

\begin{tabular}{ll}
\hline Item Most Frequently Excluded & Countries Where Exclusions Apply \\
\hline Interest Payments & Finland, France, Japan, Spain \\
Cyclically-Sensitive Expenditure & Finland, Poland, Spain, United States \\
Capital Expenditure & Croatia, Ecuador, Peru \\
Security-related spending & Israel, Peru \\
\hline
\end{tabular}

Source: FAD Fiscal Rules Dataset.

Design features vary across countries. In advanced economies, expenditure rules are often used in connection with medium-term expenditure frameworks and compliance is monitored by an independent fiscal body, a so called "Fiscal Council," whereas in emerging countries formal enforcement mechanisms are more frequent (Figure 4). ${ }^{4}$ Well-defined escape clauses are relatively rare in connection with expenditure rules. Contingencies tend to be handled by leaving a margin between the budget envelope and the expenditure ceiling (Ayuso-i-Casals, 2012).

Figure 4. Design Features of Expenditure Rules in 2013

(Number of Countries)

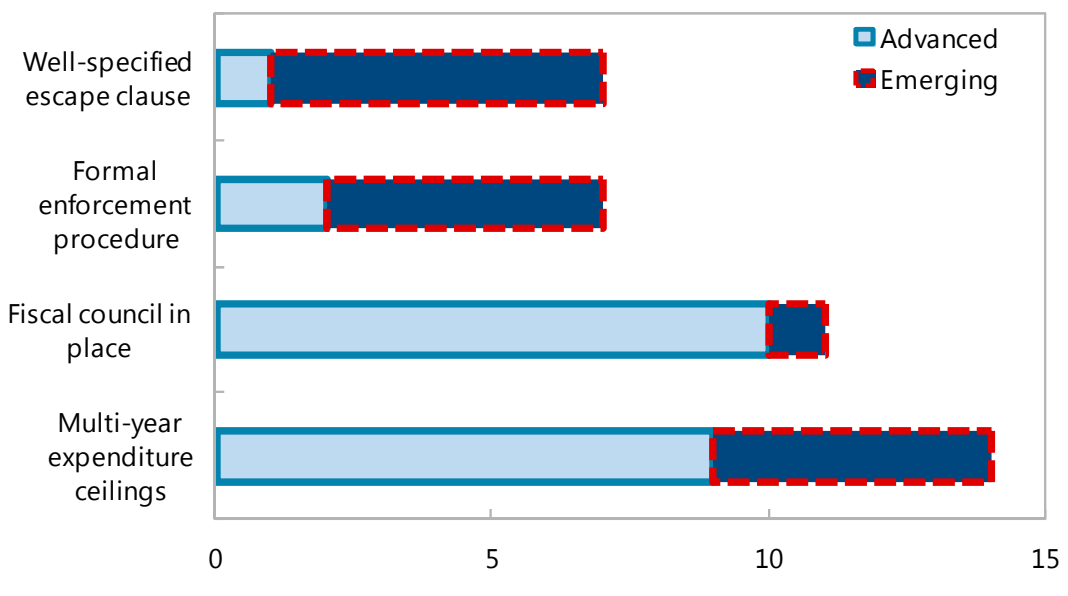

Source: FAD Fiscal Rules Database; and Authors' calculations.

\footnotetext{
${ }^{4}$ These include formal sanctions, which are often part of Fiscal Responsibility Laws, and automatic correction mechanisms.
} 


\section{Why Do COUNTRIES AdOPT AND ABANDON EXPENDITURE RULES?}

From 1985 to 2012,27 countries have introduced 31 different expenditure rules. The adoption of such rules may have been motivated by various reasons. First, governments may adopt expenditure rules to help them achieve other supranational fiscal rules. Second, coalition governments can use these rules to bind them to certain fiscal targets for the electoral period. Finally, especially in recent years, countries have adopted expenditure targets in bad economic times to rein in spending. Out of the 31 expenditure rules that have been introduced since 1985, 10 have already been abandoned either because the country has never complied with the rule or because fiscal consolidation was so successful that the government did not want to be restricted by the rule in good economic times.

Although expenditure rules are typically used in connection with other fiscal rules, they are most often not adopted at the same time as these rules (Figure 5). Only six of the 31 expenditure rules were introduced together with other rules. For instance, Brazil, Argentina, and Peru included expenditure rules in their fiscal responsibility laws as part of a wider set of reforms in 1999 and 2000. However, for 20 of the 31 cases, other fiscal rules were already in place when the expenditure rule was introduced. In particular, many European Union countries adopted national expenditure rules to help them achieve the Maastricht deficit and debt limits. Belgium, Denmark, the Netherlands, and Luxembourg introduced national expenditure rules in response to these new supranational fiscal rules after 1992. Sweden and Finland followed a couple of years later after becoming members of the European Union in 1995.

The variation in European countries' adoption of national expenditure rules can be explained by the different structure of governments. According to Hallerberg and others $(2007,2010)$, countries with ideologically dispersed coalitions will not be as willing to delegate power to a finance minister representing only one of the parties in government. Instead, it is more likely that coalition governments opt for multi-year expenditure targets, which they can credibly fix in their coalition agreement for their electoral period. Belgium, the Netherlands, Luxembourg, Sweden, and Finland set expenditure targets in their coalition agreements. Minority governments, such as in Sweden in the 1990s, have also introduced expenditure rules to agree on fiscal targets for their electoral period with the opposition in parliament. 
Most of the expenditure rules were adopted in bad economic times. In all but six cases, the implementation of the expenditure rule was preceded by a negative change in the output gap. More than one third of the expenditure rules were introduced since 2009, in response to the financial crisis. Earlier findings suggested that expenditure rules were mainly adopted following prior consolidation to lock-in fiscal adjustment (IMF, 2009). However, taking into account recent adoptions of fiscal rules in response to the crisis, less than a third of all expenditure rules were introduced after fiscal consolidation, measured as an improvement in the budget balance compared to the previous two or three years.

10 of the 31 expenditure rules have already been given up for various political and economic reasons. In six of the 10 cases, the country did not comply with the rule in the year before giving it up. Once a rule has lost its credibility, countries might not see any benefit in upholding it. In Argentina, Kosovo and Iceland, the rule was never observed and all three countries abandoned their prevailing rule when they faced global market turmoil in 2008/2009. Japan and Bulgaria also had problems complying with their rule during the financial crisis and decided to implement a new expenditure rule. Political changes were more important in other countries. In Australia, the first political commitment to an expenditure rule was only made for the life of parliament. Following an early election in 1988, the new parliament did not specify a new rule.

In some countries, there was the perception that expenditure rules fulfilled their purpose. Following successful consolidations in Belgium, Canada, and the United States in the 1990s, these countries did not see the need to follow their national expenditure rules anymore.

Especially in the United States, spending pressures increased during an economic boom at the end of the 1990s. More and more spending was made outside of the expenditure ceilings via an emergency spending category $(\mathrm{CBO}, 2003)$. The ceilings were raised ad hoc several times in the two years preceding the abandonment of the rule in 2002.

\section{What Is THE EVIDENCE?}

Combining the fiscal rules dataset with indicators on budgetary outturns from various sources (IMF databases, quantitative and qualitative ex-post budgetary assessments from fiscal councils) can help shed light on who complied with expenditure rules and when; on behavior of primary balances around the introduction of the rules; and of associated changes in public investment spending and efficiency. The results, reported below, need to be interpreted with caution, as establishing causation between institutions and policy outcomes is a perennial challenge. For instance, it could be the case that expenditure rules are primarily adopted by countries with an intrinsically strong commitment to fiscal discipline, good public expenditure management practices, or good institutions, generally, ex-ante. In addition, the relatively small sample suggests that results could be affected by outliers. 


\section{A. Compliance}

Previous studies on the impact of expenditure rules on fiscal performance have never analyzed whether countries actually comply with the rules they have adopted (Debrun and others, 2008; Wierts, 2008; Turini, 2008; Holm-Hadulla and others, 2010; Nerlich and Reuter, 2012). This section provides a compliance assessment for almost all countries with expenditure rules, covering 95 percent of the 217 countryyears since 1985. Compliance is measured as a dummy variable (i.e., it does not control for near misses) and is established using both quantitative and qualitative data from various sources such as the WEO database, country budgets and assessments by fiscal councils. ${ }^{5}$ Two points are worth highlighting. First, the assessment of compliance does not control for whether the rule was effectively binding or not. Put differently, it does not distinguish cases where the rule was met because countries really tried hard. ${ }^{6}$

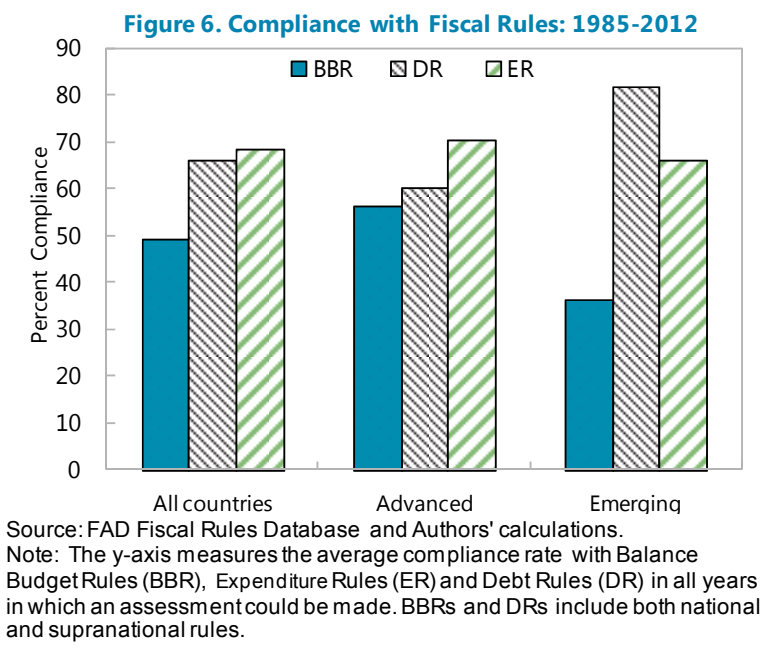
Second, and related, the compliance rates may be exaggerated if countries abandon rules once they become binding. We discuss below a couple of instances when this occurred. Overall, the analysis shows that countries comply more often with expenditure rules than with other fiscal rules. In addition, the section points to two rule characteristics that are associated with higher compliance rates. First, countries comply more often if the expenditure target is directly under the control of the government. Second, compliance with expenditure rules is higher if the rule is enshrined in law or in a coalition agreement.

\section{Comparing expenditure rules with other fiscal rules}

Countries have complied with expenditure rules for more than two-third of the time. Figure 6 shows that expenditure rules have a better compliance record than budget balance and debt rules. The only exception is the high performance of emerging market economies with debt rules. However, this can be explained by the very high compliance rates of European emerging economies with the supranational Maastricht debt rule that was not effectively binding for most of these countries. In addition, the high compliance rate with debt rules can be explained by the favorable impact of financial repression, which translated into persistent negative interest-growth differentials, on debt dynamics (Escolano, Shabunina, and Woo, 2011). The higher compliance

\footnotetext{
${ }^{5}$ Details on compliance scores are available from the authors upon request.

${ }^{6}$ The question of fiscal rules and incentives for better fiscal performance is taken up in section B.
} 
rate with expenditure rules is consistent with the fact that these rules are easy to monitor and that they immediately map into an enforceable mechanism - the annual budget itself. Besides, expenditure rules are most directly connected to instruments that the policymakers effectively control. By contrast, the budget balance, and even more so public debt, is more exposed to shocks, both positive and negative, out of the government's control.

One of the desirable features of expenditure rules compared to other rules is that they are not only binding in bad but also in good economic

Figure 7. Compliance and Type of Rule

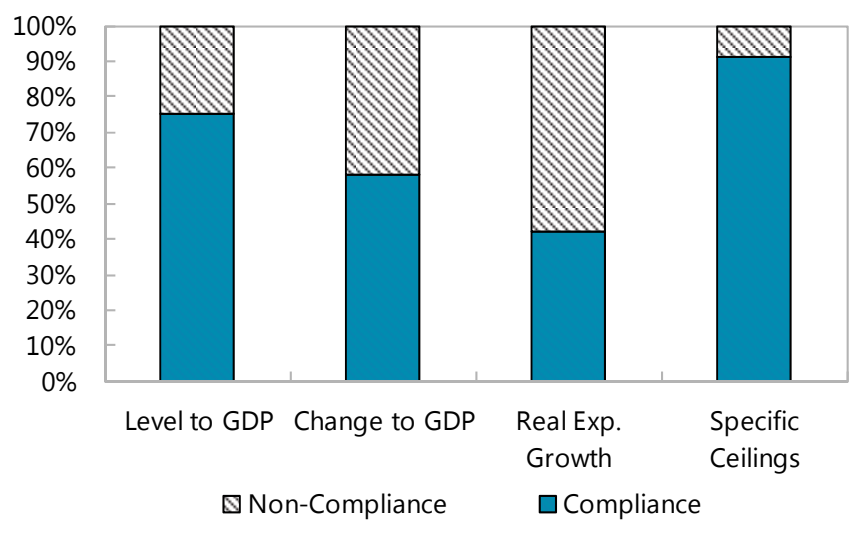

Source: FAD Fiscal Rules Database and Authors' calculations. times. The compliance rate in good economic times, defined as years with a negative change in the output gap, is at 72 percent almost the same as in bad economic times at 68 percent. In contrast to other fiscal rules, countries also have incentives to break an expenditure rule in periods of high economic growth with increasing spending pressures. For instance, Iceland never managed to comply with its expenditure rule during its economic boom in the $2000 \mathrm{~s}$. The financial and economic crisis of 2009 would have been the first time that Iceland complied with its rule. In the United States, spending pressures also undermined the expenditure rule in good economic times. Belgium and Canada gave up their expenditure rule during periods of relatively high economic growth.

\section{Which rule characteristics are associated with high compliance rates?}

Although compliance with expenditure rules is overall high, there is still a large variance between different countries' performance. While correlations between certain rule characteristics and compliance should be interpreted with caution, as establishing causation between institutions and policy outcomes is difficult, two design features are in particular associated with higher compliance rates. First, compliance is higher if the government directly controls the expenditure target. Figure 7 shows the compliance rates for different types of expenditure targets. Specific ceilings have the best performance record. For these rules, governments specify nominal targets for each individual year, which gives a clear guideline for the budget process. Although some countries, such as Finland and the Netherlands, first set these targets in real terms, they convert them in the budget process to nominal terms (Ljungman, 2008). The government controls these nominal expenditures directly. In contrast, the government does not have full control over expenditure targets if these are defined in relationship to GDP or inflation. Evidence suggests that expenditure targets specified in levels of GDP have also had a high compliance record. In many cases, however, this is because targets were often set at very high levels so that they did not lead to a binding expenditure constraint. Once this target became binding, the lack of control over GDP or inflation became apparent. Botswana, for instance, exceeded its 40 percent 
expenditure-to-GDP target by more than five percentage points due to declining demand in diamonds (IMF, 2012).

Nominal expenditure growth rules compared to GDP and real expenditure growth rules have a poor performance record for two reasons. First, the government can aim to comply with the rule, but fail due to unexpected economic shocks. For instance, Iceland targeted transfer payment growth that varied strongly, from 5.9 percent in 2003 to -7.3 percent in 2004 (Gunnarsson, 2011). One alternative is to use past macroeconomic indicators, such as Lithuania, which decided to use the average of revenue growth over the past five years as a benchmark instead of yearly changes, which provides a clear ex ante benchmark that does not vary too strongly. The government may also lose control over expenditure targets if these include local government spending. In Denmark, for instance, the rule was often broken because local governments overspend, thus breaking the overall rule for the general government (this has since been remedied by the adoption of binding expenditure ceilings which include the bulk of local government spending).

Second, the government has a lower incentive to comply with rules specified in relation to other macroeconomic factors because independent institutions, legislators or the general public cannot hold the government directly accountable for non-compliance. In several countries, the rule was so vaguely specified that even independent institutions had problems to check compliance. For instance, in Luxembourg, the central bank tried to assess the record of compliance, but had to make several assumptions to do so (Banque Centrale du Luxembourg, 2005). In contrast in countries with specific nominal ceilings, it is simple for independent institutions to control compliance. For instance, the Swedish Fiscal Council and the U.S. Congressional Budget Office increased visibility of the rule and provided an independent assessment of compliance with the nominal ceiling.

In addition to the type of expenditure target, Figure 8 shows that there is also a correlation between the legal basis of the rule and average compliance rates. Political commitments have the poorest performance record. In contrast to coalition agreements and statutory rules, political commitments do not have any binding character. Performance in the six countries with coalition agreements is at least as good as in countries with statutory rules, with a high mean compliance rate of more than 80 percent in countries with coalition agreements. Coalition agreements set expenditure caps only for the lifetime of a coalition. By contrast, political commitments and statutory rules often cap expenditures beyond an electoral period. In several instances, new governments decided to abandon the rule, not to comply with it or change quantitative targets ad 
hoc. For example, the 2007 expenditure targets in Israel were increased in an ad hoc manner once the new government was formed. In the United States, the legislature increased spending ceilings ad hoc for 2001 and 2002. Statutory laws cannot prevent these cases of non-compliance if the specific target and the coverage of the rule are not specified in the law.

\section{B. Expenditure Rules and Long-term Sustainability}

Have expenditure rules been associated with better fiscal performance? A number of existing studies focusing on European countries have shown that the presence of expenditure rules could help mitigate spending and procyclical bias (Debrun and others, 2008; Wierts 2008; HolmHadulla and others, 2010). Covering a larger sample of advanced and developing economies, new empirical analysis described here extends previous studies on expenditure rules and fiscal performance. It focuses on whether the rule has strengthened long-term sustainability, as reflected in a higher primary balance or lower primary spending after taking into account standard determinants of these variables. The underlying econometric model is due to Bohn (1998), which explains the primary balance or primary expenditure by its lagged term (to allow for persistence), the lagged gross debt (to capture long-term solvency constraint), and the output gap (to control for the cyclicality of fiscal policy). The regression model also takes into account the simultaneous existence of an expenditure rule and other rules (budget balance and debt rules). To reduce the selection bias that may be inherent when analyzing countries with expenditure rules exclusively, the econometric analysis relies on a broader and representative sample of 57 advanced and developing economies. In addition to countries with expenditure rules, this broader sample also includes comparable countries that have not introduced expenditure rules during the period of analysis (1985-2012). ${ }^{7}$

The results illustrate that countries with expenditure rules, in addition to other rules, exhibit on average higher primary balances (Table 2 ). ${ }^{8}$ Similarly, countries with expenditure rules also exhibit lower primary spending. The results are robust to the use of an alternative indicator for the presence of expenditure rules: the expenditure rule index. In addition to informing whether or not a country has an expenditure rule in place, this index also capture the comprehensiveness of the rule in place. For instance, countries where the expenditure rule covers the general government instead of the central government will have a higher index. ${ }^{9}$

\footnotetext{
${ }^{7}$ Appendix 1 provides the list of countries included in the regressions in Table 2.

${ }^{8}$ As mentioned above, the empirical analysis is subject to a caveat that applies to any empirical study of the impact of institutions on policies: reverse causality. In the absence of convincing instruments, we cannot exclude the possibility that the presence of fiscal rules reflects deep social preferences that would be the true cause of strong outcomes.

${ }^{9}$ The expenditure rule index captures the comprehensiveness of expenditure rules by aggregating their key features such as coverage, legal basis, and formal enforcement procedure. See Schaechter and others (2012) for details on the methodology to construct a similar fiscal rules index.
} 


\section{Table 2. Expenditure Rules and Fiscal Performance}

\begin{tabular}{|c|c|c|c|c|}
\hline \multirow[t]{2}{*}{ Dependent variable: } & \multicolumn{2}{|c|}{ Primary balance } & \multicolumn{2}{|c|}{ Primary expenditure } \\
\hline & $(1)$ & $(2)$ & (3) & $(4)$ \\
\hline \multirow[t]{2}{*}{ Lag primary balance } & 0.791 & 0.791 & & \\
\hline & $(28.43)^{* * *}$ & $(28.23)^{\star * *}$ & & \\
\hline \multirow[t]{2}{*}{ Lag primary expenditure } & & & 0.903 & 0.902 \\
\hline & & & $(44.46)^{* * *}$ & $(44.41)^{\star * *}$ \\
\hline \multirow[t]{2}{*}{ Lag Debt to GDP ratio } & 0.013 & 0.013 & -0.011 & -0.012 \\
\hline & $(3.47)^{\star * *}$ & $(3.59)^{\star * \star}$ & $(3.03)^{\star * *}$ & $(3.12)^{\star * *}$ \\
\hline \multirow[t]{2}{*}{ Output gap } & 0.063 & 0.061 & -0.021 & -0.019 \\
\hline & $(2.36)^{\star *}$ & $(2.28)^{\star *}$ & -0.73 & -0.66 \\
\hline \multirow[t]{2}{*}{ Expenditure rule dummy } & 0.822 & & -0.643 & \\
\hline & $(2.75)^{\star * *}$ & & $(2.07)^{\star *}$ & \\
\hline \multirow[t]{2}{*}{ Expenditure rule index } & & 0.271 & & -0.213 \\
\hline & & $(2.50)^{\star *}$ & & $(1.87)^{\star}$ \\
\hline \multirow[t]{2}{*}{ Other rules dummy } & 0.781 & 0.64 & -0.539 & -0.434 \\
\hline & $(3.35)^{* * *}$ & $(3.14)^{* * *}$ & $(2.17)^{* *}$ & $(1.98)^{* *}$ \\
\hline Observations & 1,085 & 1,085 & 1,085 & 1,085 \\
\hline Country & 57 & 57 & 57 & 57 \\
\hline
\end{tabular}

Event studies, which normalize the implementation date of each country's expenditure rule to year $t$ and a simple measure of fiscal impulse to gauge the cyclical stance of fiscal policy, illustrate that the fiscal policy tended to be counter-cyclical in the years following the introduction of an expenditure rule (Figure 9). In the case of emerging markets, this sharply contrasts with the years preceding the introduction of a rule, when fiscal policy was procyclical on average. These results confirm, for a broader sample of advanced and emerging economies, existing findings for European economies (Wierts 2008; Holm-Hadulla and others, 2010). The cyclicality indicator in Figure 9 averages fiscal impulses, with procyclical impulses entering with a positive value and countercyclical impulses with a negative value. Specifically, procyclical impulses enter the indicator as improvements in the primary balance during bad times (when growth is below potential) and the negative of deteriorations in the primary balance

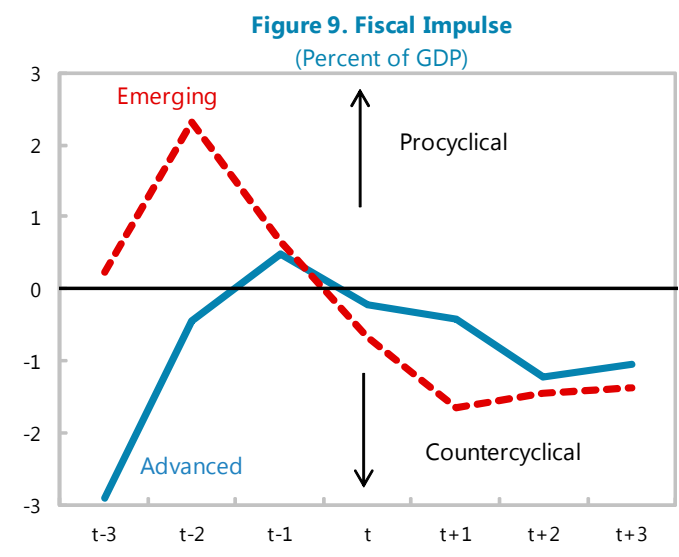

Source:FAD Fiscal Rules Dataset; and Authors' calculations. Note: Procyclical impulses are measured by the improvement in the primary balance during bad times and the deterioration in the primary balance during good times. A higher value in the graph corresponds to a more procyclical policy. A negative value corresponds to a countercyclical policy. $t$ indicates the year the rule was introduced. during good times (when growth is above potential). 


\section{Other Implications of Expenditure Rules}

\section{Expenditure rules and public investment}

Even the best designed fiscal rules can have undesirable side effects. The most common relates to the risk that policymakers seek to achieve compliance by compressing certain high-quality discretionary items, such as public investment (see Blanchard and Giavazzi, 2004). While this may be an argument to exclude public investment from expenditure rules, there are potential drawbacks to limiting the rule's coverage because it weakens the link with debt sustainability and opens the door to reclassification of spending items. $^{10}$

Expenditure rules are associated with a significant decrease in investment in emerging economies only. Similar event studies (as above) show that on average investment spending falls across countries following the implementation of an expenditure rule (Figure 10a).

Figure 10. Expenditure Rules and Spending Composition

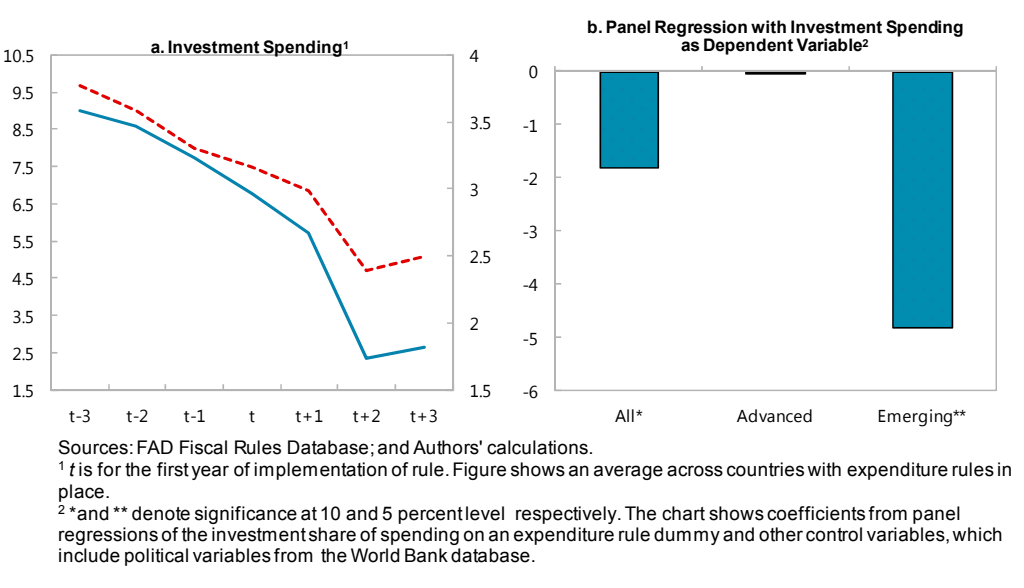
However, the result only passes the test of a panel regression for emerging economies (Figure 10b). ${ }^{11}$ The presence of well-designed medium-term budgetary frameworks, which may be more common in advanced countries, could be a mitigating factor and ensure that capital spending is not cut merely to comply with expenditure ceilings in the short term.

\section{Implications for government size and efficiency}

While the primary objective of expenditure rules is to enhance fiscal sustainability, there may be other side effects. These include a reduction in the size of government - which might in fact be the intended objective, particularly in some advanced economies - but also a reduction in the volatility of government expenditure, as result of a more medium-term orientation of the budget under expenditure rules. Lower volatility improves the predictability (and credibility) of policy and directly contributes to macroeconomic stability. Finally, expenditure rules may promote greater efficiency.

\footnotetext{
${ }^{10}$ Including through the creation of new expenditure categories.

${ }^{11}$ Details of the panel regression can be found in Appendix 2.
} 
The data provide some evidence of possible implications for government size and efficiency. Event studies illustrate that the introduction of expenditure rules is indeed followed by smaller governments both in advanced and emerging countries (Figure 11a). ${ }^{12}$
Figure 11. Expenditure Rules, Efficiency and Government Size
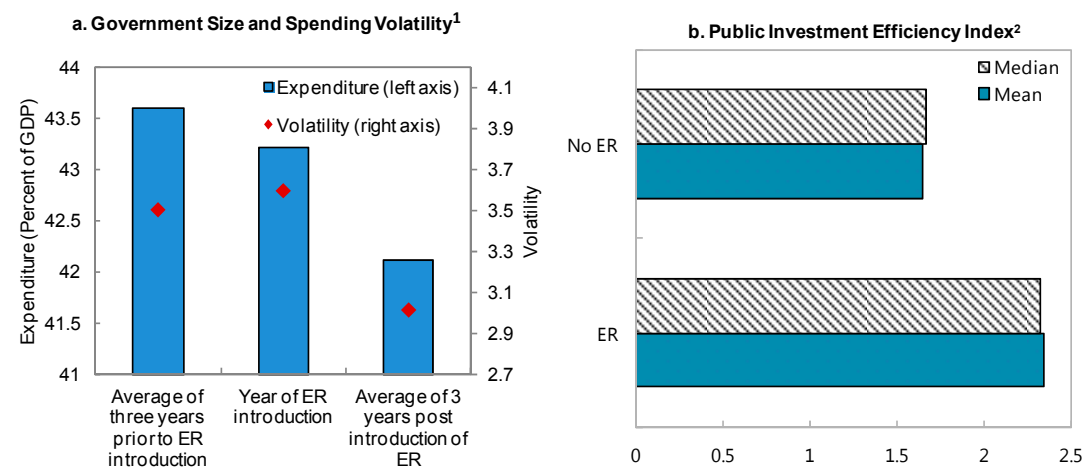

Sources: FAD Fiscal Rules Database; Dabia-Norris and others (2012); and Authors' calculations. ${ }^{1}$ Volatility is calculated as the absolute value of the percentage change in the deviation of expenditure from its trend as calculated by the HP filter.

2 The public investment efficiency index covers 71 emerging and low-income countries and captures the institutional environment underpinning public investment management across four different stages: project appraisal, selection, implementation, and evaluation. ER=expenditure rule.

The volatility of government spending is also found to decline after the introduction of an expenditure rule. ${ }^{13}$ Investigating the effect of expenditure rules on spending efficiency is constrained by data availability. The only bit of evidence is that the public investment efficiency index of DablaNorris and others (2012) is higher in countries that do have expenditure rules in place compared to those that do not (Figure 11b). ${ }^{14}$ This could be due to investment projects being prioritized more carefully relative to the case where there is no binding constraint on spending. But this conclusion is tentative at best.

\section{Expenditure rules and medium-term budgetary frameworks}

Finally, one last desirable side effect of expenditure rules is that they could encourage or foster desirable and complementary public financial management (PFM) reforms, including the introduction of a genuine medium-term budgetary framework (MTBF), and the strengthening of budget procedures, such as the adoption of top-down budgeting (Ayuso-i-Casals, 2012). The data indeed suggests that the majority of countries strengthened their medium-term fiscal frameworks either at the time of the introduction of the expenditure rule or afterwards (Figure 12).

\footnotetext{
${ }^{12}$ Given that most expenditure rules were implemented in the context of-and perhaps part of the response to "bad" economic times (see Figure 5), those patterns may not only be due to the introduction of an expenditure rule. They could also reflect that over the course of the recovery, government spending to GDP typically falls and volatility declines. Nonetheless, introducing an expenditure rule following a rise in spending during recessions can ensure that the expenditure-to-GDP ratio does not stay at an elevated level due to political pressures during the recovery.

${ }^{13}$ Following Grigoli and others (2012), spending volatility is calculated as the absolute value of the percentage change in the deviation of expenditure from its trend as calculated by the HP filter.

${ }^{14}$ This is a composite index, covering 71 countries, which measures the efficiency of public investment through a quantitative assessment of the investment process across four consecutive stages, namely: project appraisal, selection, implementation, and evaluation.
} 
Figure 12. Expenditure Rules and Medium-Term Frameworks

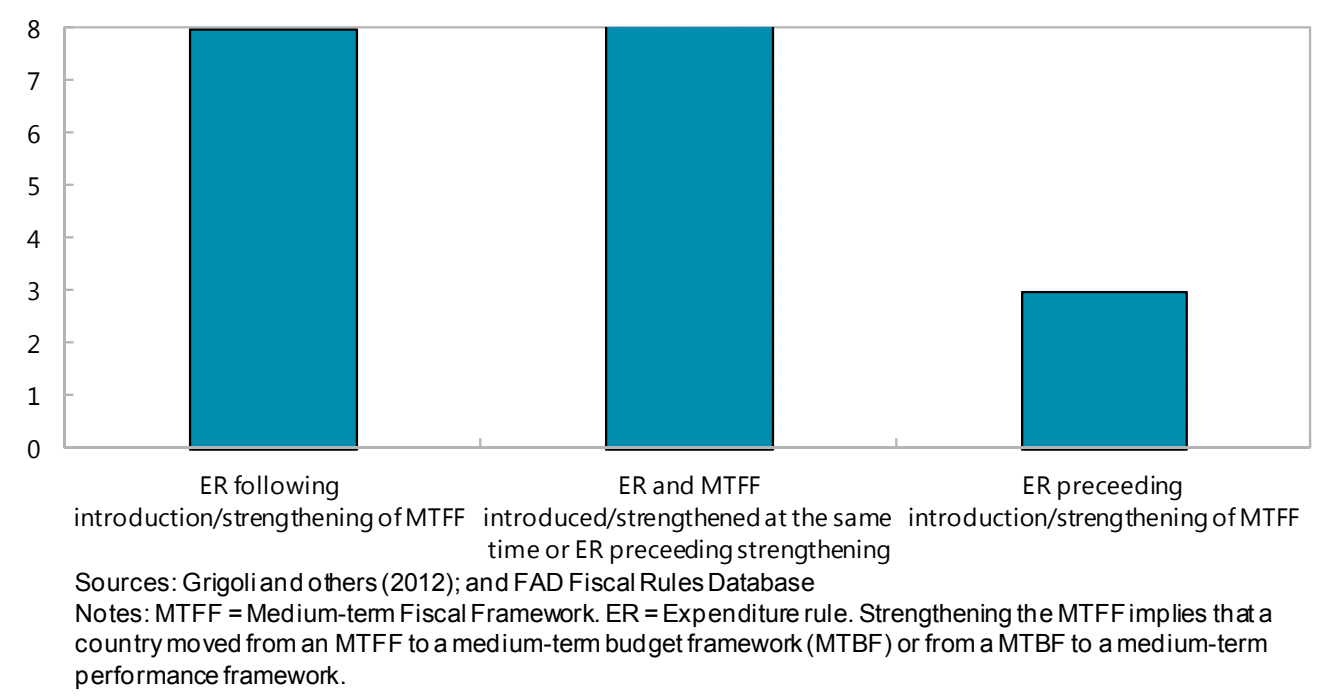

\section{Conclusions}

This paper has examined the effectiveness of expenditure rules using the fiscal rules dataset developed by Schaechter and others (2012). Overall, its findings lend support to the view that expenditure rules can foster better spending behavior if sound PFM systems are in place. Specifically, the analysis shows that:

- The compliance rate with expenditure rules is greater than for budget-balance rules, particularly if the expenditure rule is directly under the control of the government and the rule is enshrined in law or in a coalition agreement.

- The presence of expenditure rules is associated with stronger fiscal performance, that is a higher primary balance - after taking into account conventional determinants - and countercyclical policies.

- Expenditure rules are associated with lower levels of public investment in emerging market economies, where weaker PFM systems may be less effective in preventing policymakers to defer high-quality discretionary spending for the sake of complying with the rule.

These results need to be interpreted with caution given the relatively limited experience with expenditure rules (33 rules during 1985-2013). Moreover, in most cases, expenditure rules are generally used in conjunction with budget-balance and/or debt rules. While this is needed to link the rule to debt sustainability, such simultaneity complicates the identification of their impact. 
Appendix 1. Country List for Regressions on Expenditure Rules and Fiscal Performance

\begin{tabular}{ll}
\hline Advanced & Emerging \\
economies & economies \\
\hline Australia & Argentina \\
Austria & Brazil \\
Belgium & Bulgaria \\
Canada & Chile \\
Cyprus & China \\
Czech Republic & Colombia \\
Denmark & Egypt \\
Estonia & Haiti \\
Finland & Honduras \\
France & Hungary \\
Germany & India \\
Greece & Indonesia \\
Hong Kong SAR & Latvia \\
Ireland & Lithuania \\
Israel & Malaysia \\
Italy & Mexico \\
Japan & Moldova \\
Korea & Nicaragua \\
Netherlands & Peru \\
New Zealand & Philippines \\
Norway & Poland \\
Portugal & Romania \\
Singapore & Russia \\
Slovak Republic & South Africa \\
Slovenia & Thailand \\
Spain & Turkey \\
Sweden & Ukraine \\
Switzerland & \\
United Kingdom & \\
United States & \\
\hline
\end{tabular}




\section{Appendix 2. Additional Regression Results}

\section{Section C: Public Investment}

Table 1. Fixed Effects Panel Regressions 1980-2010, Capital Spending as a Share of Total Spending as the Dependent Variable ${ }^{16}$

(Percent of GDP)

\begin{tabular}{lccc} 
& All & Advanced & Emerging \\
\hline Expenditure rule dummy & -1.8 & -0.01 & -4.9 \\
& $(1.0)^{\star}$ & $(0.8)$ & $(2.3)^{\star *}$ \\
Executive & 0.6 & 0.2 & 1.3 \\
& $(1.4)$ & $(1.4)$ & $(2.9)$ \\
Legelec & -0.1 & 0.4 & -1.0 \\
& $(0.9)$ & $(0.7)$ & $(2.5)$ \\
Constant & 8.4 & 2.7 & 17.4 \\
& $(0.6)^{* * *}$ & $(0.6)^{* * *}$ & $(1.4)^{\star * *}$ \\
& & & \\
R-squared (overall) & & & \\
Observations & 0.02 & 0.00 & 0.01 \\
Number of countries & 490 & 274 & 176 \\
\hline
\end{tabular}

Sources: FAD Fiscal Rules Database; World Economic outlook database; World Bank Database of Political Institutions

Notes: LEGELEC $=1$ if there was a legislative election in this year. EXELEC $=1$ if there was an executive election in this year.

Robust standard errors in parentheses; ${ }^{*}$ denotes significance at 10 percent level, ${ }^{* *}$ denotes significance at 5 percent; ${ }^{* *}$ denotes significance at 1 percent.

${ }^{16}$ A Hausman (1978) test was conducted to check whether a fixed effects model is preferable to a random effects model. The hypothesis that the individual-level effects are adequately captured by a random effects model can be rejected at the 1 percent level of significance. 
Appendix 3. Expenditure Rules Details

\begin{tabular}{|c|c|c|c|c|c|c|c|c|}
\hline Country & $\begin{array}{l}\text { Statutory } \\
\text { Base }\end{array}$ & Coverage & Target/Constraint & Description & Timeframe & $\begin{array}{l}\text { Escape } \\
\text { Clause }\end{array}$ & $\begin{array}{l}\text { Independent } \\
\text { Body Monitors } \\
\text { Implementation }\end{array}$ & FRL \\
\hline Argentina & L & GG & Change to GDP & $\begin{array}{l}\text { Primary expenditure cannot grow more than nominal } \\
\text { GDP or at most stay constant in periods of negative } \\
\text { nominal GDP growth. }\end{array}$ & $2000-08$ & No & Yes & Yes \\
\hline Australia & L & CG & $\begin{array}{l}\text { Real expenditure } \\
\text { growth rate }\end{array}$ & $\begin{array}{l}\text { Real growth in spending is constrained to } 2 \text { percent a } \\
\text { year once the economy recovers and grows above } \\
\text { trend. Once the budget returns to surplus, and while } \\
\text { the economy is growing at or above trend, the } \\
\text { government will maintain expenditure restraint by } \\
\text { retaining a } 2 \text { percent annual cap on real spending } \\
\text { growth, on average, until surpluses are at least } 1 \\
\text { percent of GDP }\end{array}$ & 2009- & No & No & Yes \\
\hline Australia & PC & CG & Change to GDP & $\begin{array}{l}\text { Government expenditure cannot be raised as a } \\
\text { proportion of GDP in 1985-86 and over the life of the } \\
\text { Parliament }\end{array}$ & $1986-88$ & No & No & No \\
\hline Belgium & CA & CG & $\begin{array}{l}\text { Real expenditure } \\
\text { growth rate }\end{array}$ & $\begin{array}{l}\text { Real growth of primary expenditure of CG ought to be } \\
\text { equal or be less than } 0 \text { percent. }\end{array}$ & 1993-98 & No & Yes & No \\
\hline Botswana & L & CG & Level to GDP & $\begin{array}{l}\text { Ceiling on the expenditure-to-GDP ratio of } 40 \text { percent. } \\
30 \text { percent of total expenditure should be directed } \\
\text { toward development spending, which includes all } \\
\text { capital spending and the recurrent spending for health } \\
\text { and education. }\end{array}$ & $2003-$ & No & No & No \\
\hline Brazil & L & GG & Other & $\begin{array}{l}\text { (i) Personnel expenditure is limited to } 50 \text { percent of net } \\
\text { current revenue for the federal government, and } 60 \\
\text { percent for states and municipalities. (ii) permanent } \\
\text { spending mandates cannot be created without } \\
\text { permanent revenue increases or spending cuts, (iii) } \\
\text { The government sets numerical multiyear ceilings for } \\
\text { expenditure (for the current year and indicative targets } \\
\text { for the next two years). }\end{array}$ & $2001-$ & Yes & No & Yes \\
\hline Bulgaria & L & GG & Level to GDP & Ceiling on the expenditure-to-GDP ratio of 40 percent. & $2012-$ & No & No & No \\
\hline Bulgaria & PC & GG & Level to GDP & Ceiling on the expenditure-to-GDP ratio of 40 percent. & 2006-09 & No & No & No \\
\hline
\end{tabular}




\begin{tabular}{|c|c|c|c|c|c|c|c|c|}
\hline Country & $\begin{array}{l}\text { Statutory } \\
\text { Base }\end{array}$ & Coverage & Target/Constraint & Description & Timeframe & $\begin{array}{l}\text { Escape } \\
\text { Clause }\end{array}$ & $\begin{array}{l}\text { Independent } \\
\text { Body Monitors } \\
\text { Implementation }\end{array}$ & FRL \\
\hline Canada & $\mathrm{L}$ & CG & Specific ceiling & $\begin{array}{l}\text { Federal spending control act set clear nominal } \\
\text { expenditure limits from FY 1991-1992 to 1995-1996 }\end{array}$ & 1992-96 & No & Yes & No \\
\hline Croatia & L & GG & Change to GDP & $\begin{array}{l}\text { The temporary rule calls for general government } \\
\text { expenditure cuts of } 1 \text { percent of GDP a year until at } \\
\text { least a primary balance of zero is achieved in nominal } \\
\text { terms. Since } 2014 \text {, a new expenditure rule indicates } \\
\text { that real growth in public expenditures cannot exceed } \\
\text { potential GDP growth unless the extra spending is } \\
\text { financed by discretionary revenue measures. }\end{array}$ & $2012-13$ & Yes & Yes & Yes \\
\hline Denmark & PC & GG & $\begin{array}{l}\text { Real expenditure } \\
\text { growth rate }\end{array}$ & $\begin{array}{l}\text { Real growth in public expenditures cannot exceed } \\
\text { potential GDP growth which is a (rough) measure of } \\
\text { structural development in the tax base. If growth in } \\
\text { expenditures increases beyond potential GDP growth, } \\
\text { it must be financed by specific discretionary measures, } \\
\text { which increase revenues. }\end{array}$ & 2012- & No & No & No \\
\hline Denmark & PC & GG & Level to GDP & $\begin{array}{l}\text { Public consumption as a share of cyclically adjusted } \\
\text { GDP should be reduced to } 26.5 \text { percent by } 2015 \text {. }\end{array}$ & $2009-11$ & No & No & No \\
\hline Denmark & PC & GG & $\begin{array}{l}\text { Real expenditure } \\
\text { growth rate }\end{array}$ & $\begin{array}{l}\text { Target of public consumption as a percentage of } \\
\text { cyclically adjusted GDP and real growth in public } \\
\text { consumption. }\end{array}$ & 2007-08 & No & No & No \\
\hline Denmark & PC & GG & $\begin{array}{l}\text { Real expenditure } \\
\text { growth rate }\end{array}$ & $\begin{array}{l}\text { Real public consumption growth capped at } 0.5 \text { percent } \\
\text { per year } 1.0 \text { percent during } 2002-05\end{array}$ & 1994-2006 & No & No & No \\
\hline Ecuador & L & GG & Other & $\begin{array}{l}\text { Permanent expenditure cannot be higher than } \\
\text { permanent revenue though both are unclearly defined. }\end{array}$ & $2011-$ & No & No & Yes \\
\hline Finland & $\mathrm{CA}$ & CG & Specific ceiling & $\begin{array}{l}\text { Annual limits to government expenditure for the four- } \\
\text { year terms of office of the government. Limits are set in } \\
\text { real terms for primary non-cyclical expenditure (about } \\
75 \text { percent of total central government spending, about } \\
37 \text { percent of total general government spending). }\end{array}$ & $2003-$ & No & No & No \\
\hline
\end{tabular}

CInternational Monetary Fund. Not for Redistribution 


\begin{tabular}{|c|c|c|c|c|c|c|c|c|}
\hline Country & $\begin{array}{c}\text { Statutory } \\
\text { Base }\end{array}$ & Coverage & Target/Constraint & Description & Timeframe & $\begin{array}{l}\text { Escape } \\
\text { Clause }\end{array}$ & $\begin{array}{l}\text { Independent } \\
\text { Body Monitors } \\
\text { Implementation }\end{array}$ & FRL \\
\hline France & $\begin{array}{l}\text { L (2011-); } \\
\text { PC (1998- } \\
2010)\end{array}$ & CG & $\begin{array}{l}\text { Real expenditure } \\
\text { growth rate }\end{array}$ & $\begin{array}{l}\text { Targeted increase of expenditure in real terms, or } \\
\text { targeted increase of expenditure excluding interest } \\
\text { payments and pensions in nominal terms. The stricter } \\
\text { provision applies. }\end{array}$ & $1998-$ & No & Yes & No \\
\hline Hungary & L & GG & $\begin{array}{l}\text { Real expenditure } \\
\text { growth rate }\end{array}$ & Cap on real expenditure growth & $2010-11$ & No & Yes & Yes \\
\hline Iceland & PC & CG & $\begin{array}{l}\text { Real expenditure } \\
\text { growth rate }\end{array}$ & $\begin{array}{l}\text { Real expenditure growth limit of the central government } \\
\text { ( } 2 \text { percent for public consumption and } 2.5 \text { percent for } \\
\text { transfers) }\end{array}$ & $2004-08$ & No & No & No \\
\hline Israel & L & CG & $\begin{array}{l}\text { Real expenditure } \\
\text { growth rate }\end{array}$ & $\begin{array}{l}\text { Provision for limiting real growth of the central } \\
\text { government fiscal expenditure ( } 1.7 \text { percent from 2007). } \\
\text { For the biannual budget adopted July 2009, the rules } \\
\text { were relaxed to allow a real growth of expenditure of } 3 \\
\text { percent for } 2009 \text {. The Deficit Reduction and Budgetary } \\
\text { Expenditure Limitation Laws (2010) make spending } \\
\text { growth a function of public debt-rising, as the gap falls } \\
\text { between actual debt and the objective of reducing it to } \\
60 \text { percent of GDP; and rising with trend GDP- } \\
\text { measured as a } 10 \text { year moving average-and with } \\
\text { projected inflation. This formula caps real spending } \\
\text { growth in } 2011 \text { at } 2.6 \text { percent. }\end{array}$ & $2005-$ & No & Yes (since 2009) & No \\
\hline Japan & PC & CG & Specific ceiling & $\begin{array}{l}\text { "Overall Expenditure Limit" (the amount of the General } \\
\text { Account Expenditure, excluding debt repayment and } \\
\text { interest payment, should not exceed that of the } \\
\text { previous fiscal year). Reconstruction-related } \\
\text { expenditures shall be managed separately from other } \\
\text { expenditures, accompanied with their financial } \\
\text { resources (cutting other expenditures, non-tax } \\
\text { revenues including sales of government's assets, and } \\
\text { tax revenues by special taxes for reconstruction) }\end{array}$ & $2011-$ & No & No & No \\
\hline
\end{tabular}

CInternational Monetary Fund. Not for Redistribution 


\begin{tabular}{|c|c|c|c|c|c|c|c|c|}
\hline Country & $\begin{array}{l}\text { Statutory } \\
\text { Base }\end{array}$ & Coverage & Target/Constraint & Description & Timeframe & $\begin{array}{l}\text { Escape } \\
\text { Clause }\end{array}$ & $\begin{array}{l}\text { Independent } \\
\text { Body Monitors } \\
\text { Implementation }\end{array}$ & FRL \\
\hline Japan & PC & CG & Specific ceiling & $\begin{array}{l}\text { In 2006, the government set numerical targets (cabinet } \\
\text { decision) by spending category (e.g., public } \\
\text { investment, social security etc). The } 2006 \text { targets were } \\
\text { intended to be valid through FY2011 and indeed were } \\
\text { valid for FY2007 and FY2008 budgets. But the targets } \\
\text { were abandoned for FY2009 due to the crisis. }\end{array}$ & $2007-09$ & No & No & No \\
\hline Kosovo & PC & GG & $\begin{array}{l}\text { Real expenditure } \\
\text { growth rate }\end{array}$ & $\begin{array}{l}\text { Ceiling on current expenditure growth of } 0.5 \text { percent } \\
\text { per year in real terms. }\end{array}$ & $2006-08$ & No & No & No \\
\hline Lithuania & L & CG & Other & $\begin{array}{l}\text { If the CG budget recorded a deficit on average over the } \\
\text { past } 5 \text { complete years, the annual growth of the state } \\
\text { budget appropriations (excl. EU funds) may not exceed } \\
\text { one half of (or } 0.5 \text { times) the average growth rate of the } \\
\text { state budget revenue (excl. EU funds) of those } 5 \text { years. }\end{array}$ & $2009-$ & Yes & No & No \\
\hline Luxembourg & CA & CG & Change to GDP & $\begin{array}{l}\text { In the course of the legislative period (per coalition } \\
\text { agreement), public expenditure growth is maintained at } \\
\text { a rate compatible with the medium-term economic } \\
\text { growth prospects which is quantified. From } 2010 \text {, the } \\
\text { target was to bring expenditure growth back to the } \\
\text { medium-term growth prospects once the } \\
\text { countercyclical response to the crisis has been phased } \\
\text { out. }\end{array}$ & 1995-2012 & No & No & No \\
\hline Mongolia & L & CG & Change to GDP & $\begin{array}{l}\text { Expenditure growth cannot exceed the growth of non- } \\
\text { mineral GDP from } 2013 \text {. }\end{array}$ & 2013- & Yes & No & Yes \\
\hline Namibia & $\mathrm{CA}$ & CG & Level to GDP & Public expenditure levels below 30 percent of GDP. & 2011- & No & No & No \\
\hline
\end{tabular}

CInternational Monetary Fund. Not for Redistribution 


\begin{tabular}{|c|c|c|c|c|c|c|c|c|}
\hline Country & $\begin{array}{l}\text { Statutory } \\
\text { Base }\end{array}$ & Coverage & Target/Constraint & Description & Timeframe & $\begin{array}{l}\text { Escape } \\
\text { Clause }\end{array}$ & $\begin{array}{c}\text { Independent } \\
\text { Body Monitors } \\
\text { Implementation }\end{array}$ & FRL \\
\hline Netherlands & $\mathrm{CA}$ & GG & Specific ceiling & $\begin{array}{l}\text { Real expenditure ceilings are fixed for total expenditure } \\
\text { (covering CG, health care and social security; covers } \\
\text { about } 90 \text { percent of GG expenditure) and sectoral } \\
\text { expenditure for each year of government's four-year } \\
\text { office term. Coverage of expenditure was changed in } \\
\text { recent years: from } 2007-10 \text { interest payments were } \\
\text { excluded; since } 2009 \text {, expenditure is defined in net } \\
\text { terms, i.e. gross expenditure minus non-tax revenues, } \\
\text { from } 2009-10 \text { expenditure excluded unemployment and } \\
\text { social assistance benefits. If overruns are forecast, the } \\
\text { Minister of Finance proposes corrective action. }\end{array}$ & $1994-$ & No & No & No \\
\hline Peru & L & CG & $\begin{array}{l}\text { Real expenditure } \\
\text { growth rate }\end{array}$ & $\begin{array}{l}\text { Real growth current expenditure ceiling of } 2 \text { percent } \\
\text { (2000-02), } 3 \text { percent (2003-08) and } 4 \text { percent since } \\
2009 \text {. Since April 2012, infrastructure maintenance is } \\
\text { excluded from the expenditure cap as are current } \\
\text { expenditures associated with some social programs } \\
\text { and equipment for military and police forces. }\end{array}$ & $2000-$ & Yes & No & Yes \\
\hline Poland & L & CG & $\begin{array}{l}\text { Real expenditure } \\
\text { growth rate }\end{array}$ & $\begin{array}{l}\text { Overall increase in CG discretionary spending and all } \\
\text { newly enacted spending cannot exceed } 1 \text { percentage } \\
\text { point in real terms (based on CPI inflation) (defined in } \\
\text { the Public Finance Act as a temporary rule, but } \\
\text { envisaged to be replaced by a permanent rule once the } \\
\text { excessive deficit procedure has been abrogated). }\end{array}$ & 2011 - & No & No & No \\
\hline Romania & L & GG & Change to GDP & $\begin{array}{l}\text { Total GG expenditure growth should not exceed } \\
\text { projected nominal GDP for next three years until } \\
\text { budget balance is in surplus. Moreover, personnel } \\
\text { expenditure limits are binding for two years as set out } \\
\text { in MTBF. }\end{array}$ & $2010-$ & Yes & Yes & Yes \\
\hline
\end{tabular}

CInternational Monetary Fund. Not for Redistribution 


\begin{tabular}{|c|c|c|c|c|c|c|c|c|}
\hline Country & $\begin{array}{c}\text { Statutory } \\
\text { Base }\end{array}$ & Coverage & Target/Constraint & Description & Timeframe & $\begin{array}{l}\text { Escape } \\
\text { Clause }\end{array}$ & $\begin{array}{l}\text { Independent } \\
\text { Body Monitors } \\
\text { Implementation }\end{array}$ & FRL \\
\hline Russia & $\mathrm{L}$ & CG & Other & $\begin{array}{l}\text { The rule sets a ceiling on expenditures (oil revenue at } \\
\text { the "base" oil price, plus all nonoil revenues, plus a net } \\
\text { borrowing limit of } 1 \text { percent of GDP). Oil revenues } \\
\text { above the "base" oil price need to be saved in the } \\
\text { Reserve Fund until it reaches } 7 \text { percent of GDP } \\
\text { (though there are some allowable exceptions to this } \\
\text { under the law). }\end{array}$ & $2013-$ & Yes & Yes & Yes \\
\hline Spain & L & GG & Change to GDP & $\begin{array}{l}\text { The annual increase in spending by the state, regional } \\
\text { and local governments may not exceed the medium- } \\
\text { term growth reference rate set by the Ministry of } \\
\text { Economic Affairs and Competitiveness as the } 10 \text {-year } \\
\text { average potential growth rate - based on the past five } \\
\text { years and projections for current year and future four } \\
\text { years. Interest and non-discretional expenditure on } \\
\text { unemployment benefits are excluded. The rule also } \\
\text { excludes the portion of expenditure, financed with } \\
\text { specifically earmarked funds from the EU, and state } \\
\text { transfers to the regions and local governments, linked } \\
\text { to financing arrangements. }\end{array}$ & $2012-$ & Yes & Yes & Yes \\
\hline Sweden & $\begin{array}{l}\text { L (2010-); } \\
\text { CA (1997- } \\
2009)\end{array}$ & $C G+S S$ & Specific ceiling & $\begin{array}{l}\text { Nominal expenditure ceiling for CG and pension } \\
\text { system set for a three-year period with the outer year } \\
\text { added annually. Ceilings cannot be adjusted except for } \\
\text { technical issues. A budgetary margin is used as a } \\
\text { buffer. Interest expenditure is excluded from the ceiling. }\end{array}$ & $1997-$ & No & Yes (since 2007) & No \\
\hline United States & L & CG & Specific ceiling & $\begin{array}{l}\text { In August } 2011 \text {, Congress enacted discretionary } \\
\text { spending caps, saving about } \$ 900 \text { billion over the next } \\
\text { decade. As a result of the in the event of a failure to } \\
\text { adopt agree on a medium-term comprehensive deficit } \\
\text { reduction plan. These additional spending cuts (the so- } \\
\text { called sequester) came into effect in March } 2013 \text {, and } \\
\text { were These additional cuts, if not repealed by } \\
\text { Congress, will expected to produce savings of about } \\
\text { US } \$ 1.2 \text { trillion over a decade, with one-half of that } \\
\text { amount coming from defense spending and the other } \\
\text { half from domestic programs, excluding Social } \\
\text { Security, Medicaid, parts of Medicare, and certain other } \\
\text { entitlement programs. A bipartisan budget agreement } \\
\text { on December } 26,2013 \text { partially replaced the sequester } \\
\text { in fiscal years } 2014 \text { and } 2015 \text { with small mandatory } \\
\text { savings and new revenue from non-tax measures. }\end{array}$ & $2011-$ & No & Yes & No \\
\hline
\end{tabular}

CInternational Monetary Fund. Not for Redistribution 


\begin{tabular}{|c|c|c|c|c|c|c|c|c|}
\hline Country & $\begin{array}{c}\text { Statutory } \\
\text { Base }\end{array}$ & Coverage & Target/Constraint & Description & Timeframe & $\begin{array}{l}\text { Escape } \\
\text { Clause }\end{array}$ & $\begin{array}{l}\text { Independent } \\
\text { Body Monitors } \\
\text { Implementation }\end{array}$ & FRL \\
\hline United States & $\mathrm{L}$ & CG & Specific ceiling & $\begin{array}{l}\text { Annual appropriations limit adopted under the Budget } \\
\text { Enforcement Act (BEA) of } 1990 \text { for discretionary } \\
\text { spending (allowed to lapse at the end of FY 2002). }\end{array}$ & $\begin{array}{l}1991 \\
-2002\end{array}$ & No & Yes & No \\
\hline
\end{tabular}

Notes: L: legal; CA; coalition agreement; PC: political commitment. CG: central government; GG: general government; SS: social security. FRL= Fiscal Responsibility Law. 


\section{REFERENCES}

Alesina A., and S. Ardagna, 2012, "What Makes Fiscal Adjustments Successful?" unpublished.

Ayuso-i-Casals, J., 2012, "National Expenditure Rules: Why How and When," Economic Papers 473 (Brussels: European Commission).

Banque Centrale du Luxembourg, 2005, "La situation économique et financière," BCL Bulletin 2005/3 (Luxembourg).

Blanchard, O.J., and F. Giavazzi, 2004, "Improving the SGP Through A Proper Accounting of Public Investment,” CEPR Discussion Paper No. 4220 (London: The Centre for Economic Policy Research).

Congressional Budget Office, 2003, “An Analysis of the President's Budgetary Proposal for Fiscal Year 2004," (Washington), March. available at: http://www.cbo.gov/sites/default/files/cbofiles/ftpdocs/41xx/doc4129/03-31analysispresidentbudget-final.pdf.

Debrun, X., L. Moulin, A. Turrini, J., Ayuso-i-Casals, and M. S. Kumar, 2008, "Tied to the Mast? The Role of National Fiscal Rules in the European Union," Economic Policy, Vol. 54, pp. 297-362.

Debrun, X., 2014, “How Expenditure Rules Can Help Get Public Spending Right,” Public Financial Management Blog Post available at: http://blogpfm.imf.org/pfmblog/2014/06/how-expenditure-rules-can-help-public-spendingright.html.

Dabla-Norris, E., J. Brumby, A. Kyobe, Z. Mills, and C. Papageorgiou, 2012, "Investing in Public Investment: An Index of Public Investment Efficiency," Journal of Economic Growth, Vol. 17, No. 3, pp. 235-66.

Escolano, J., A. Shabunina, and J. Woo, 2011, "The Puzzle of Persistently Negative Interest Rate-Growth Differentials: Financial Repression or Income Catch-up?” IMF Working Paper 11/260 (Washington: International Monetary Fund).

Grigoli, F., Z. Mills, M. Verhoeven, and R. Vlaicu, 2012, "MTEFs and Fiscal Performance," World Bank Policy Research Paper 6186 (Washington: World Bank).

Gunnarsson, G., 2011, “Reforming Iceland's Fiscal Framework,” mimeo.

Hallerberg, M., R. Strauch, and J. von Hagen, 2007, "The design of fiscal rules and forms of governance in European Union countries," European Journal of Political Economy, Vol. 23, No. 2, pp. 338-59. 
Hallerberg, M., Strauch, R., and S. Ylaoutinen, 2010, "Political Power, Fiscal Institutions and Budgetary Outcomes in Central and Eastern Europe," Journal of Public Policy, Vol. 30, No. 1, pp. 45-62.

Holm-Hadulla, F., Hauptmeier, S., and P. Rother, 2010, “The impact of numerical expenditure rules on budgetary discipline over the cycle," Working Paper Series 1169 (Brussels: European Central Bank).

International Monetary Fund, 2009, "Fiscal Rules-Anchoring Expectations for Sustainable Public Finances" (Washington). Available at: https://www.imf.org/external/np/pp/eng/2009/121609.pdf.

— 2012 , Botswana: 2012 Article IV Consultation (Washington).

—_, 2014, October Fiscal Monitor-Public Expenditure Reforms: Making Difficult Choices (Washington).

Ljungman, G., 2008, “Expenditure Ceilings: A Survey,” IMF Working Paper 08/282 (Washington: International Monetary Fund).

Organisation for Economic Co-operation and Development, 2012, Restoring Public Finances (Paris).

Schaechter, A., T. Kinda, N. Budina, and A. Weber, 2012, "Fiscal Rules in Response to the Crisis - Toward the "Next-Generation" Rules. A New Dataset," IMF Working Paper 12/187 (Washington: International Monetary Fund).

Tornell, A., and P. Lane 1999, “The voracity effect," American Economic Review, Vol. 89, pp. 22-46.

Weingast, B., K. Shepsle, and C. Johnson, 1981, "The political economy of benefits and costs: A neoclassical approach to distributive politics," Journal of Political Economy, Vol. 89, pp. 642-64.

Wierts, P., 2008, “How do expenditure rules affect fiscal behaviour?” DNB Working Paper 166 (Amsterdam: De Nederlandsche Bank). 